Bull. Egypt. Soc. Physiol. Sci. 40(1), 166-179

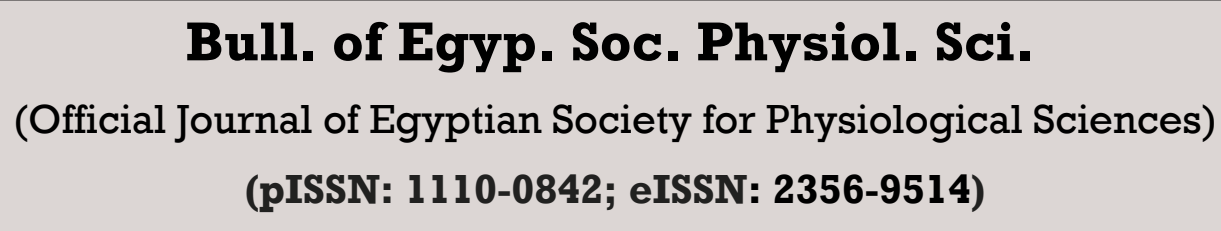

Bull. of Egyp. Soc. Physiol. Sci.

(pISSN: 1110-0842; eISSN: 2356-9514)

\title{
Leptin exerts a bone protective effect in ovariectomized rats via inhibiting osteoclastogenesis
}

\author{
Mona A. Said ${ }^{1}$, Heba M. Abdel-Kareem ${ }^{2}$ and Hend A. Abdallah ${ }^{1}$
}

1. Physiology department, Faculty of Medicine, Benha University, Egypt.

2. Medical biochemistry department, Faculty of Medicine, Benha University, Egypt.

Received: 26 August 2019 Accepted: 31 Oct 2019

Available online: 22 Jan 2020

\section{Keywords}

- Leptin

- Osteoporosis

- Bone markers

- RANKL

- OPG

- Osteoclastogenesis

\section{Abstract}

Osteoporosis is one of the most prevalent bone diseases especially among postmenopausal women. This study was conducted on 36 female rats divided into three equal groups; i) Sham-operated, ii) Ovariectomized (OVX), iii) Leptin treated ovariectomized group. At the end of experiment, blood was collected for measurement of serum alkaline phosphate (ALP), calcium (Ca), phosphorus $(\mathrm{P})$, osteocalcin, receptor activator of nuclear factor $\kappa \mathrm{B}$ ligand (RANKL) and osteoprotegerin (OPG). Urine was collected for measurement of urinary deoxypyridoline/creatinine (DPY/Cr). After eight weeks of treatment, administration of leptin inhibited OVX-induced weight gain with uterotrophic effect, decreased bone turnover markers (urinary DPY/Cr, serum osteocalcin and serum ALP) and serum RANKL while it resulted in significant increase in serum calcium and OPG. Moreover, it markedly decreased expression of RANKL and increased expression of OPG in proximal femur, and thus lowered the RANKL/OPG ratio. These findings suggests that the anti-osteoporotic effect of leptin was by inhibiting osteoclastogenesis via modulating RANKL/OPG ratio. Leptin had potential to be developed as alternative therapeutic agents of osteoporosis induced by postmenopause. 


\section{INTRODUCTION}

Last century has shown a steady increase on life expectancy that has been followed by a raise in the incidence of the age related diseases, such as diabetes, hypertension and osteoporosis [1]. Osteoporosis is one of the most common bone remodeling disease that affects almost 200 million people worldwide mostly in postmenopausal women and elderly men, but it is more commonly seen in women than men because women have a lower peak bone mass and because of the estrogen hormonal changes that occur at the menopause. It is characterized by an abnormal bone remodeling, i.e. excess bone resorption and less bone formation [2]. The most important consequence of osteoporosis is bone fractures especially in the vertebrae, hip and forearm. Particularly, hip fractures are an important cause of morbidity and mortality [3].

Osteoporosis develops insidiously and its clinical symptoms may not appear until fractures occur. Therefore, the main goal is the detection of patients at risk for future fractures and to ensure the prevention of these fractures through treatment [4]. The measurement of bone formation and resorption markers provide systemic and dynamic information about the bone tissue. In addition, bone microarchitecture is an important factor in ensuring the bone quality. Bone microarchitecture may play a decisive role in bone fragility, independently of bone mineral density (BMD) [5].

The RANKL/RANK/OPG system plays a pivotal role in the regulation of bone metabolism. Receptor activator of nuclear factor $\mathrm{\kappa B}(R A N K)$ is a receptor located on surface osteoclasts (precursor and mature). Ligands of RANK are osteoprotegerin $(O P G)$ and receptor activator of nuclear factor $\mathrm{kB}$ ligand (RANKL) synthesized and secreted primarily by osteoblasts and bone marrow stromal cells. When RANK is activated by the RANKL, a signaling cascade begins, causing osteoclast differentiation and increased bone resorption. $O P G$, which acts as a decoy receptor for $R A N K L$, inhibits this interaction and suppresses activation of osteoclasts. The balance between expressions of $R A N K L$ and $O P G$ in osteoblasts and bone marrow stromal cells regulates bone resorption. The importance of this regulation in bone metabolism is explained by the facts that chemical induced blockade of $R A N K L$ is an efficient treatment for osteoporosis [6].

Osteoporosis and obesity are two major health problems all over the world. Extensive epidemiological studies have reported that body fat is strongly correlated to bone mass. In fact, both male and female obese subjects have generally increased BMD. To date, the protective effect of obesity has been partially explained by a combination of hormonal and mechanical factors. Adipose tissue is the main site of aromatization of androgen to estrogen contributing to increase of BMD in both postmenopausal women and men [7]. Moreover, increased body weight enhances mechanical loading on bone, stimulating bone formation and, consequently, leading to increased bone mass. An important association between obesity and low trauma fractures has recently been reported in post-menopausal women compared with normal weight controls, challenging the classical view of obesity as a factor promoting bone health [8].

Leptin is a $16-\mathrm{kDa}$ protein hormone secreted by the white fat tissue. Since 1994, the scientist in Rockefeller University had already 
detected and cloned this adipokine. Various cells such as the undifferentiated bone marrow mesenchymal stem cells (BMSCs), hematopoietic cells, adipocytes, osteoblasts and osteoclasts can express leptin receptor. Also, researchers have proved its major role in appetite modification, energy consumption, and body weight regulation.

Thomas et al. (1999) had already found that leptin could promote osteogenesis differentiation in BMSCs. However, the function of leptin in bone formation is still controversial [9].

So, the aim of this study was to assess the possible effect of leptin supplementation on bone metabolism in ovariectomized adult female rats, by measuring indices of bone resorption and bone formation (bone biomarkers). Also given the importance of RANKL/OPG system in bone metabolism, this study evaluated the effect of leptin administration on RANKL/OPG gene expression and serum $R A N K L / O P G$ ratio.

\section{Materials and Method:}

\subsection{Experimental Animals:}

All experiments were performed in accordance with national animal care guidelines and were preapproved by the Ethics Committee at Faculty of Medicine, Benha University. The present study was conducted on 36 female Sprague-Dawley rats weighing from 150 to $200 \mathrm{~g}$ (4-6 months). The rats were obtained from the Animal House at the Faculty of veterinary medicine, Benha University. They were housed under optimal laboratory conditions (relative humidity $65 \pm 5 \%$, temperature $22 \pm 2^{\circ} \mathrm{C}$, and $12 \mathrm{~h}$ light and $12 \mathrm{~h}$ dark cycle). During the whole study, a standard commercial pellet diet was given to all rats.

\subsection{Experimental protocol}

Rats were classified into 3 equal groups of 12 rats in each:

a- Group I (Sham operated group): Received a single dose of phosphate buffer solution (PBS) given intraperitoneally (i.p.) daily for eight weeks.

b- Group II (OVX group): Rats in which osteoporosis was induced by bilateral ovariectomy and received a single dose of PBS given i.p. daily for eight weeks [10].

c- Group III (OVX + Leptin): Ovariectomized rats received exogenous recombinant rat leptin $(10 \mu \mathrm{g} / \mathrm{kg}$ body weight) dissolved in PBS (i.p.) beginning on day 1 after ovariectomy and daily for eight weeks [11]. We purchased rat leptin from (Sigma Chemical Co., St. Louis, MO, USA L5037)

\subsection{Induction of osteoporosis}

After fasting for $18 \mathrm{~h}$, female rats were anesthetized, using intraperitoneal i.p. sodium pentobarbital (40 mg/kg body weight) purchased from (Sigma-Aldrich, St. Louis, MO, USA). Osteoporosis was induced in groups II and III by bilateral ovariectomy using the dorsal approach according to Lane et al. (2003) [12]. In brief, each anesthetized rat underwent a surgical procedure of a single longitudinal skin incision on the dorsal midline at the level of the kidneys. Both ovaries were ligated and excised. Ovariectomy was evidenced by failure to detect ovarian tissue and by marked atrophy of the uterine horns. Because rats and humans share similarities in skeletal responses to estrogen deficiency, the mature OVX rat is considered to be a suitable animal model for studying early postmenopause-induced bone loss 
[13]. Sham operated group undergo the same surgical procedure without excision of the ovaries.

\subsection{Sample collection and biochemical analysis}

At the end of the eight weeks, rats were anesthetized with pentobarbital sodium $(50 \mathrm{mg} / \mathrm{kg}$, i.p. Sigma-Aldrich, St. Louis, MO, USA). Blood was withdrawn from abdominal aorta for estimating serum calcium $(\mathrm{Ca})$, serum phosphorus $(\mathrm{P})$, serum alkaline phosphatase (ALP) and serum osteocalcin. Serum Ca, P, and ALP were measured using standard colorimetric methods with commercial kits Sigma-Aldrich, St. Louis, MO, USA) according to the method described by Chen et al. (2016) [14]. while serum osteocalcin concentration was estimated by an enzyme linked immunoassay (ELISA) kit (Biomedical Technologies Inc., Stoughton, MA, USA) according to the method described by Risteli and Risteli (1993) [15]. Serum osteoprotegerin $(O P G)$, and receptor activator of nuclear factor- $\mathrm{kB}$ ligand $(R A N K L)$ concentrations were determined using an ELISA kit (Beijing North Biotechnology Co., Beijing, China) according to the manufacturer's instruction then the ratio of serum RANKL/OPG was then calculated. Urine was collected for measurement of deoxypyridoline/creatinine $(D P Y / C r)$, a biochemical indicator of collagen degradation which reflects the extent of bone resorption. DPY was measured by an ELISA kit (Quidel Corporation, San Diego, CA, USA) according to the method described by Robins et al. (1994) [16]. Urinary $\mathrm{Cr}$ was determined using the picric acid method according to Xie et al. (2005) [17]. Urinary DPY levels were expressed as the ratio of urinary $D P Y$ to $C r(D P Y / C r)$.

\subsection{Reverse transcription-quantitative} polymerase chain reaction (RT-qPCR)
RNA was isolated from the proximal femur bone tissue of all rats in different groups using the RNeasy mini kit for extraction (QiagenGermany) according to the manufacturer's protocol. The RNA concentration and purity were measured using nanodrop spectrophotometer (Biowave II Germany). The samples with ratio of A260 /A280 (1.9 - 2.3) were considered pure and confident for use. Then RNA was reverse transcribed into cDNA and quantitative PCR was performed using the Ready Mix PCR Reaction Mix kit (iScriptTM One-Step RT-PCR Kit with SYBR $®$ Green (Bio-Rad, USA) in a $50 \mu$ volume. To maximize specificity, reactions were assembled on ice. Thermal cycling conditions were: $10 \mathrm{~min}$ at $50^{\circ} \mathrm{C}, 5 \mathrm{~min}$ at $95^{\circ} \mathrm{C}$ then 40 cycles $10 \mathrm{sec}$ at $95^{\circ} \mathrm{C}$ $30 \mathrm{sec}$ at $55^{\circ} \mathrm{C}, 1 \mathrm{~min}$ at $55^{\circ} \mathrm{C}$ using Rotorgene real time PCR system (Qiagen- S.Korea). $\beta$-actin was used as a reference gene for internal control. The PCR primers sequences of the studied genes are shown below with final primer concentration of $300 \mathrm{~nm}$ is effective in most reactions; Data were analyzed using the comparative $\mathrm{Ct}\left(2^{-\Delta \Delta \mathrm{CT}}\right)$ method. We used $\beta$-actin as endogenous control gene for normalization $[\mathbf{1 8}, \mathbf{1 9}]$.

The PCR primers sequences of the studied genes are shown in table (1) 
Table (1): Primer sequence of the studied genes

\begin{tabular}{lll}
\hline Gene & \multicolumn{1}{c}{ Forward primer } & \multicolumn{1}{c}{ Reverse primer } \\
\hline $\boldsymbol{O P G}$ & ACGCGGTTGTGGGTGCGATT & AAGACCGTGTGCGCCCCTTG \\
$\boldsymbol{R A N K L}$ & CAGAAGATGGCACTCACTGCA & CACCATCGCTTTCTCTGCTCT \\
$\boldsymbol{\beta}$-actin & GTGACATCCACACCCAGAGG & ACAGGATGTCAAAACTGCCC \\
\cline { 2 - 3 }
\end{tabular}

\subsection{Statistical analysis}

All analyses were performed using the program Statistical Package for Social Sciences version 16 (SPSS Inc, Chicago, IL, USA). The data are listed as the mean \pm standard deviation (SD). Comparisons among groups, in all studied parameters, were analyzed by using one-way analysis of variance (ANOVA) test and Bonferroni's Multiple Comparison Test. Probability of chance $(\mathrm{P}<0.05)$ was considered statistically significant.

\section{Results :}

\subsection{Effect of leptin administration on body} and uterine weight

The final body weight of the OVX group was significantly higher than that of the sham operated group $(P<0.001)$. The OVX-induced body weight gain was significantly inhibited by administration of leptin $(P<0.001)$. The final uterine weight was significantly reduced in the OVX group as compared to the sham group $(P<$ 0.001). Treatment with leptin prevented the reduction of uterine weight compared to the OVX group $(P<0.001)$ (table 2, fig. 1 and fig.2).

\subsection{Effect of leptin administration on serum} calcium and phosphorus levels

The present data shown in table 2 and fig. 3 revealed significant decrease in serum calcium levels $(P<0.001)$ in OVX rats when compared with the sham operated group.
Ovariectomized rats treated with leptin resulted in significant increase $(P<0.001)$ of serum Ca levels when compared with the ovariectomized rats while non-significant changes in the serum $\mathrm{P}$ was observed between the studied groups.

\subsection{Effect of leptin administration on bone turnover markers}

As shown in table 2 and fig 4, bilateral ovariectomy in rats resulted in statistically significant changes in bone turnover markers as compared to the sham operated group: there was a significant increase in bone formation markers including serum ALP $(P<0.001)$, serum osteocalcin $(P<0.001)$ together with a significant increase in bone resorption marker: urinary DPY/Cr $(P<0.001)$. Administration of leptin resulted in significant decrease in serum $\operatorname{ALP}(P<$ $0.001)$, serum osteocalcin $(P<0.001)$ and urinary DPY/Cr $(P<0.001)$ compared to OVX group.

\subsection{Effect of leptin administration on serum} $O P G, R A N K L$ and $R A N K L / O P G$ ratio:

Compared with the sham operated group, bilateral ovariectomy in OVX group resulted in significant decrease in serum $O P G$, significant increase in serum RANKL and significant increase in the $R A N K L / O P G$ ratio $(P<0.001)$. Leptin administration, by contrast, significantly increased serum $O P G$, decreased serum RANKL and hence $R A N K L / O P G$ ratio $(P<0.001)$ (Table 2 and fig. $5)$. 


\subsection{Effect of leptin administration on OPG and}

\section{RANKL expression:}

Compared with the sham operated group,OPG gene expression was markedly decreased while the RANKL expression was markedly increased in OVX group.
On the contrary, Administration of leptin in group III led to OPG gene up-regulation and RANKL gene down-regulation when compared to the OVX rats (Fig.6) .

Table (2): Body weight, uterine weight, bone turnover markers, serum RANKL, OPG and RANKL/OPG ratio in each experimental group (Mean \pm Standard deviation).

\begin{tabular}{|c|c|c|c|}
\hline Groups & \multirow{2}{*}{$\begin{array}{c}\text { Group I } \\
\text { (Sham operated } \\
\text { group) }\end{array}$} & \multirow{2}{*}{$\begin{array}{c}\text { Group II } \\
\text { (OVX group) }\end{array}$} & \multirow{2}{*}{$\begin{array}{c}\text { Group III } \\
\text { (OVX + Leptin) }\end{array}$} \\
\hline Parameter & & & \\
\hline Final body weight (g) & $250.23 \pm 4.54$ & $320.37 \pm 5.27 *$ & $275.71 \pm 4.71 \#$ \\
\hline Uterine weight (g) & $2.41 \pm 0.13$ & $0.55 \pm 0.04 *$ & $1.86 \pm 0.16 \#$ \\
\hline Serum Ca $(\mathrm{mg} / \mathrm{dl})$ & $11.29 \pm 0.21$ & $8.33 \pm 0.15 *$ & $10.62 \pm 0.31 \#$ \\
\hline Serum P $(\mathbf{m g} / \mathrm{dl})$ & $4.94 \pm 0.19$ & $5.01 \pm 0.25$ & $4.96 \pm 0.46$ \\
\hline Serum ALP (mg/dl) & $278.20 \pm 6.41$ & $372.52 \pm 16.81 *$ & $300.68 \pm 8.61 \#$ \\
\hline Serum osteocalcin (mg/dl) & $75.11 \pm 1.45$ & $95.16 \pm 1.17 *$ & $78.92 \pm 1.66 \#$ \\
\hline Urinary DPY/Cr. (nmol/mg) & $31.98 \pm 0.56$ & $62.24 \pm 1.54 *$ & $42.64 \pm 1.07 \#$ \\
\hline Serum OPG (ng/ml) & $6.87 \pm 0.47$ & $2.54 \pm 0.65 *$ & $5.74 \pm 0.91 \#$ \\
\hline Serum RANKL (ng/ml) & $1.88 \pm 0.44$ & $4.16 \pm 0.49 *$ & $1.95 \pm 0.61 \#$ \\
\hline RANKL/OPG ratio & $0.27 \pm 0.03$ & $1.64 \pm 0.05 *$ & $0.34 \pm 0.07 \#$ \\
\hline
\end{tabular}

Data is expressed as mean \pm standard deviation, $P$. value $=$ probability of chance, $P<0.05$ is significant tested by using One-way analysis of variance (ANOVA) test and Bonferroni's Multiple Comparison Test

* Significant difference $(\mathrm{P}<0.05)$ vs the sham operated group.

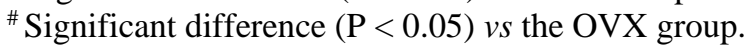

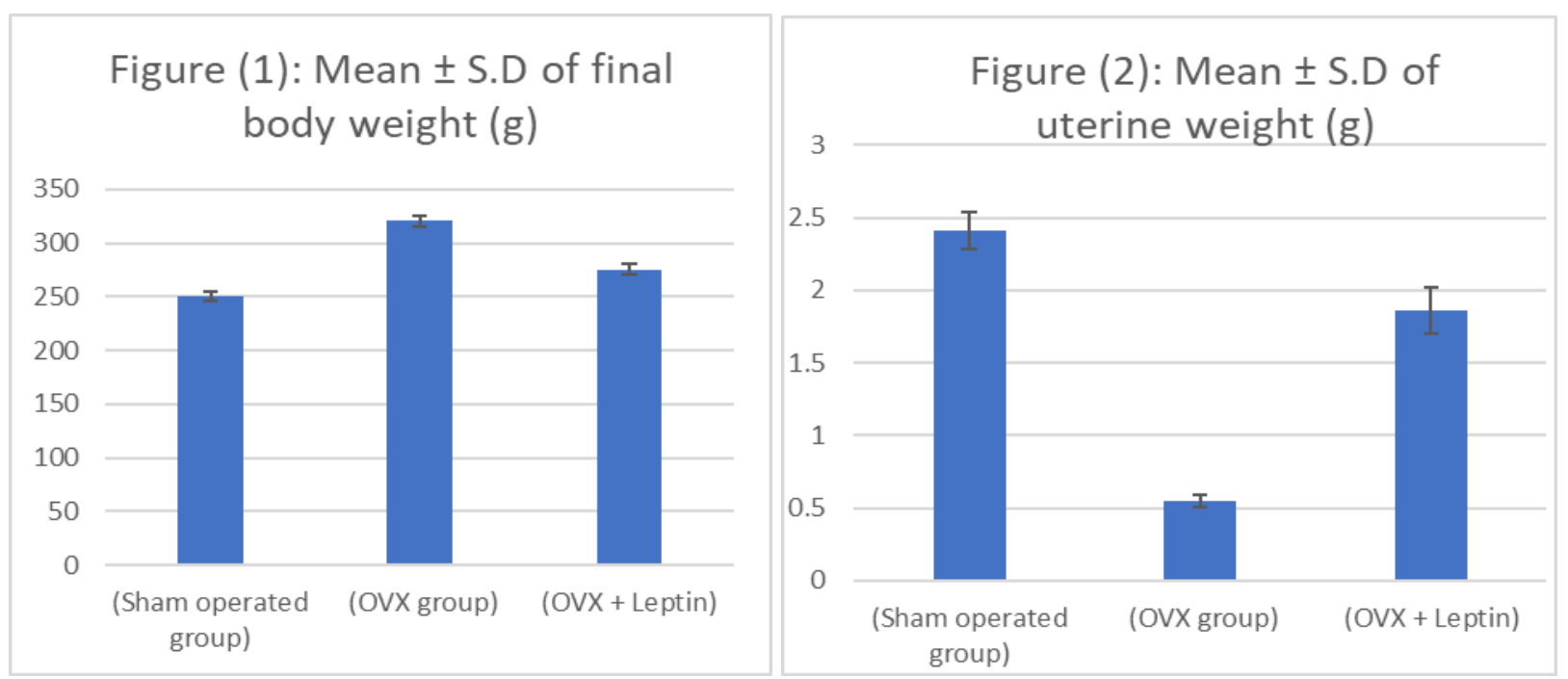


Figure (3): Mean \pm S.D of serum $\mathrm{Ca}(\mathrm{mg} / \mathrm{dl})$ and serum $\mathrm{P}$ $(\mathrm{mg} / \mathrm{dl})$

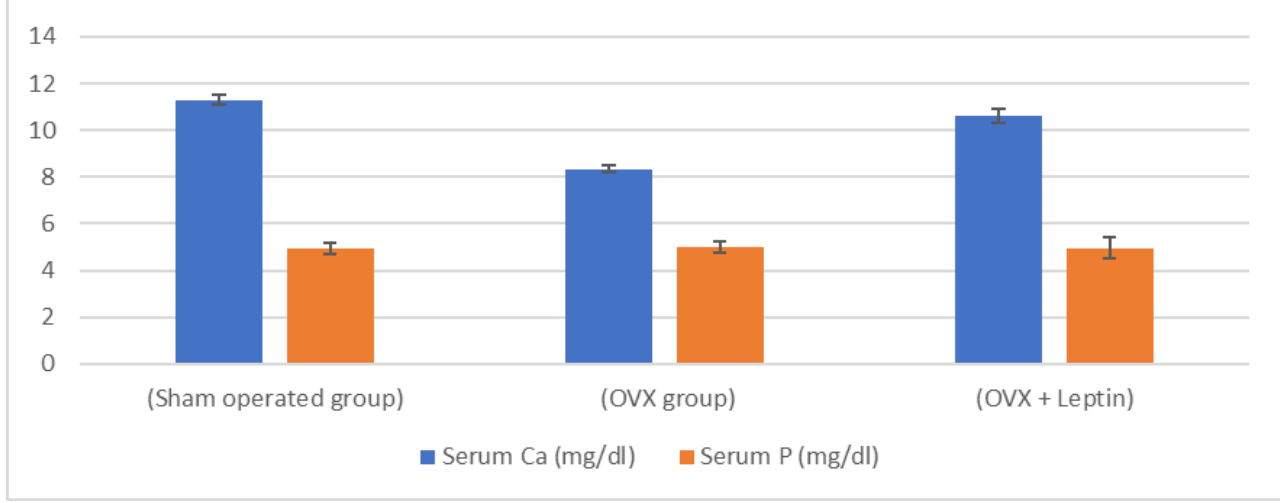

Figure (4): Mean \pm S.D of serum ALP (mg/dl) , serum osteocalcin $(\mathrm{mg} / \mathrm{dl})$ and Urinary DPY/Cr. $(\mathrm{nmol} / \mathrm{mg})$

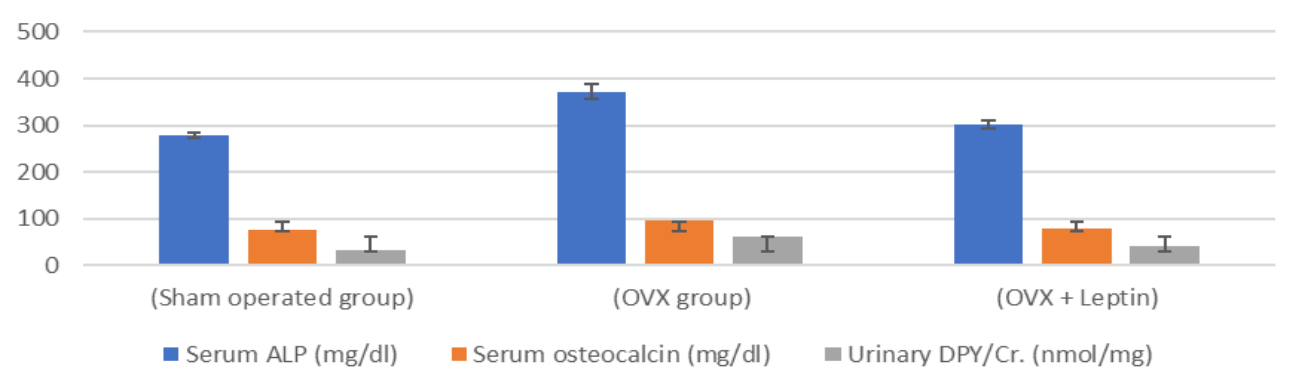

Figure (5): Mean \pm S.D of serum OPG $(\mathrm{ng} / \mathrm{ml})$, serum RANKL $(\mathrm{ng} / \mathrm{ml})$ and RANKL/OPG ratio

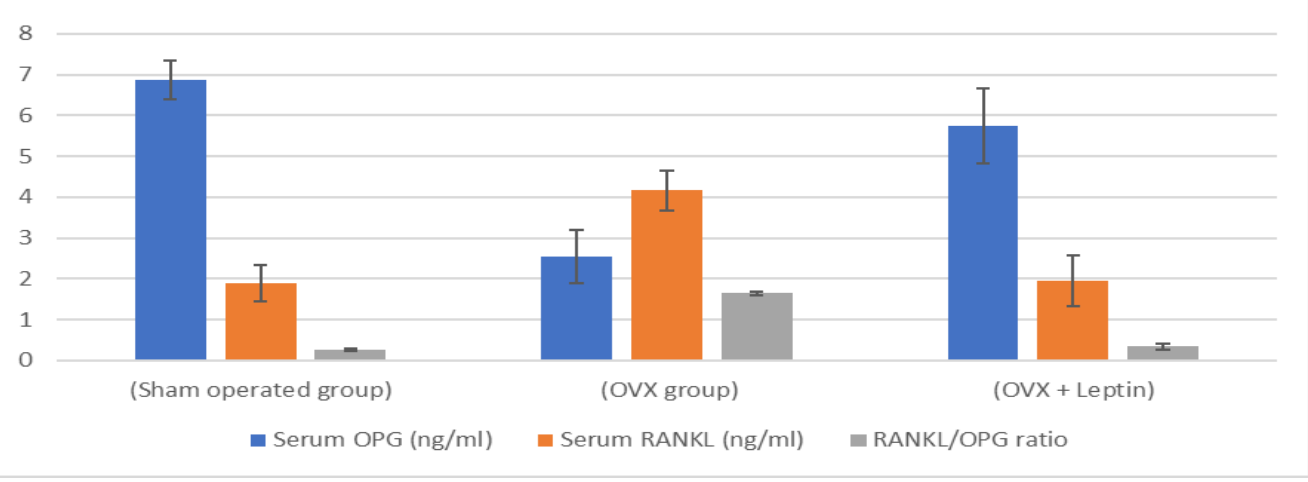

Figure (6): OPG m.RNA expression and RANKL m.RNA expression

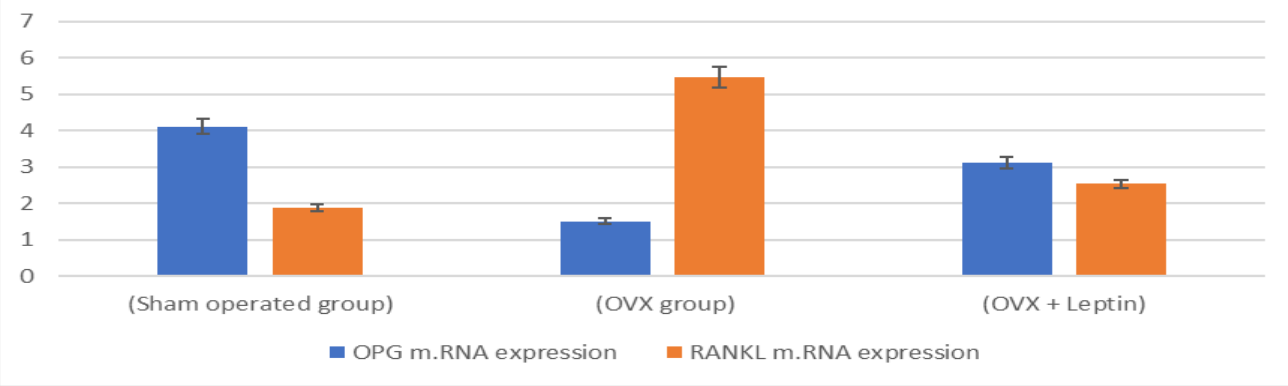




\section{Discussion}

Osteoporosis is considered as a fundamental health problem worldwide, especially in Egypt, as Egyptian women have generally lower BMD compared to women in western countries. In Egypt, about $6.5 \%$ of females aged above 20 years suffer from osteopenia and $10-13 \%$ of postmenopausal women suffer from osteoporosis [20].

Osteoporosis evolves by the three main mechanisms which are an insufficient strength during growth and peak bone mass, exaggerated bone resorption, and insufficient formation of new bone during remodeling. Interaction between these mechanisms leads the development of fragile bone tissue. Hormonal factors strongly determine the rate of bone resorption include lack of estrogen (e.g. as a result of menopause) increases bone resorption, as well as decreasing the deposition of new bone that normally takes place in weightbearing bones [21]. The ovariectomized (OVX) rat is considered an excellent preclinical animal model correctly emulate the major clinical feature of the estrogen depleted human skeleton and the response of therapeutic agents [22].

In this study, OVX rats have significantly higher body weight and lower uterine weight compared to sham operated rats. This is in agreement to previous studies who stated that as a result of estrogen deficiency, body weight is increased by fat deposition while the uterine weight is decreased due to atrophy of the uterus $[23,24]$. Increased body weight can be additional stimulus for new bone formation, serving as a partial protection against the osteopenia. Treatment with leptin for eight weeks prevented body weight gain and loss of uterine weight induced by estrogen deficiency in OVX rats. Leptin is partially effective in modulating appetite and limiting weight gain [25].

The bone is a dynamically active tissue that undergoes continuous turnover via bone formation and resorption. It is regulated by functions of osteoblasts and osteoclasts. It is well known that the decreased estrogen level after menopause or ovariectomy results in an imbalance in the bone remodeling process as bone resorption increases without adequate new bone formation. This occurs as a result of apoptosis of osteoblasts and suppression of osteoclast apoptosis [26]. In accordance with such findings, the present study revealed that bilateral ovariectomy induced osteoporosis in rats and resulted in significant changes in bone turnover markers demonstrated by a significant increase in the urinary DPY/Cr. (marker of bone resorption) and increase in both serum ALP and serum osteocalcin (markers of bone formation) when compared to the sham operated group. In agreement with these results, Bhardwaj et al. (2013) reported an increase in the markers of bone resorption following ovariectomy in female rats [27]. In addition, Su et al. (2013) and Cho et al. (2012) reported an increase in serum osteocalcin level in OVX rats [23, 28]. Treatment with leptin caused significant decrease of serum alkaline phosphatase, and serum osteocalcin and significant decrease in urinary DPY/Cr. compared with OVX group which were in congruent with the results of Abdel-Sater and Mansour (2013) [29].

Calcium represents another important factor in the pathogenesis of osteoporosis. It has 
been postulated that $\mathrm{Ca}$ metabolism plays a significant role in bone turnover, and deficiency of $\mathrm{Ca}$ leads to impaired bone mineralization [30]. Results of the current study showed significant decrease in serum Ca level in OVX rats while it showed non-significant change in serum $\mathrm{P}$ when compared to the sham operated group. Similar results were reported by Hassan et al. (2012) [31]. In addition, menopause is usually associated with decreased intestinal $\mathrm{Ca}$ absorption which could be attributed to reduced circulating 1, 25dihydroxyvitamin D levels [32]. Estrogen deficiency in menopause was associated with changes in expression of many proteins involved in distal tubular calcium reabsorption resulting in increased renal excretion of $\mathrm{Ca}$ [33]. In ovariectomized rats the increase in calcium level after leptin administration could be explained by its contribution to aberrant regulation of renal 25hydroxyvitamin D3 metabolism through increasing the gene expression of renal 1 $\alpha$-hydroxylase, which catalyzes 1, 25-dihydroxyvitamin D3 synthesis [34].

The $R A N K L / R A N K / O P G$ system plays a key role in the regulation of bone metabolism and the RANKL/OPG ratio determines osteoclastogenesis in the bone. In this study, we found that bilateral ovariectomy resulted in decreased serum $O P G$ and decreased $O P G$ mRNA expression in rat femur meanwhile increased serum RANKL and increased expression of $R A N K L$ in rat femur and resulted in significant increase in $R A N K L / O P G$ ratio in OVX rat compared with Sham operated rats, which is consistent with previous studies [35. 36. 37]. Leptin administration modulated this course significantly. Leptin treatment resulted in significant increase in serum and mRNA expression of $O P G$ and it decreased serum and mRNA expression of RANKL thus decreasing $R A N K L / O P G$ ratio. These results indicated that one of actions of leptin in inhibiting bone loss lay in modulatory effect on $R A N K L / O P G$ ratio. Leptin was found to decrease RANKL and increased osteoprotegerin $(O P G)$ in women with hypothalamic amenorrhea together with an increase in bone mass [38].

According to the in vitro and in vivo studies, leptin has a protective role on bone mass. On one hand, $X \boldsymbol{u}$ et al. (2009) found that leptin could stimulate the proliferation and osteoblastic differentiation of both BMSCs and dental stem cells [39]. Moreover, the serum leptin is greatly increased in fractured rat after injury indicated a positive relationship between the leptin and bone regeneration [40]. Ogueh et al. (2000) has shown that there is a negative correlation between fetal leptin levels and levels of cross-linked carboxylterminal telopeptide of type I collagen, a marker of bone resorption. They assumed that leptin decreased bone resorption with the overall effect of increasing bone mass in humans and concluded that leptin might play a major role in fetal bone metabolism as part of its impact on fetal development and growth. These results all indicated that leptin might increase bone formation and decrease bone resorption with the overall effect of increasing bone mass [41].

The leptin receptor can be found in adult primary osteoblasts and chondrocytes, suggesting that the effects of leptin on bone growth and metabolism may be direct [42]. Locally, bone marrow adipocytes have been found to secrete leptin that may mediate leptin's local effects on bone. Although leptin may act peripherally on 
bone, central leptin administration in leptin deficient $(o b / o b)$ mice has been found to restore bone mass to control levels. Lesion of the ventromedial hypothalamus (VMH) have been found to prevent the restoration of bone mass with leptin administration for $o b / o b$ mice, suggesting that the VMH is key to leptin's control of bone mass [43]. Leptin may also act indirectly by decreasing serotonin synthesis and inhibiting serotonergic receptors [44] inhibiting glucocorticoids, activating thyroid hormones through the hypothalamic-pituitary-thyroid axis thus may help to improve bone growth [45].

\section{Conclusion and Recommendations}

Based on the data of the present study, we conclude that leptin may play an important protective role in bone metabolism by inhibiting ostoclatogenesis. Consequently, it could be a major contributing factor to the protective effect of obesity against osteoporosis.

\section{List of abbreviations}

ALP, Alkaline phosphatase; BMD, Bone mineral density; BMSCs, Bone marrow mesenchymal stem cells; Cr.; Creatinine; DPY, Deoxypyridoline; ELISA, Enzyme linked immunoassay; OPG, osteoprotegerin; OVX, Ovariectomized; PCR, Polymerase chain reaction, RANKL, Receptor activator of nuclear factor $\mathrm{\kappa B}$ ligand;

\section{Conflict of interest}

The authors declare no conflict of interest.

\section{References}

1. Blagosklonny, M.V. Prospective treatment of age-related diseases by slowing down aging. Am. J. Pathol. 2012; 181: 1142-1146. doi: 10.1016/j.ajpath.2012.06.024.
2. Canalis, E. New treatment modalities in osteoporosis. Endocr. Pract. 2010; 16(5): 855 - 63. doi: 10.4158/EP10048.RA.

3. Pisani, P., Renna, M.D., Conversano, F., Casciaro, E, Di Paola, M., Quarta, E., Muratore, M., Casciaro, S. Major osteoporotic fragility fractures: risk factor updates and societal impact. World J Orthop 2016; 7: 171-181. 10.5312/wjo.v7.i3.171.

4. Vestergaard, P., Rejnmark, L., Mosekilde, L. Osteoporosis is markedly underdiagnosed: a nationwide study from Denmark. Osteoporos. Int. 2005; 16(2): 134 - 141. doi: 10.1007/s00198-004-1680-8.

5. Dalle Carbonare, L., Valenti, M.T., Bertoldo, F., Zanatta, M., Zenari, S., Realdi, G. Lo Cascio, V., Giannini, S. Bone microarchitecture evaluated by histomorphometry. Micron. 2005; 36(7-8): 609 616.

doi:

10.1016/j.micron.2005.07.007.

6. Kobayashi, Y., Udagawa, N., Takahashi, N. Action of RANKL and OPG for osteoclastogenesis. Crit. Rev. Eukaryot. Gene Exp. 2009; 19(1): 61 - 72. PMID: 19191757.

7. De Laet, C., Kanis, J.A., Odén, A., Johanson, H., Johnell, O., Delmas, P., Eisman, J.A., Kroger, H., Fujiwara, S., Garnero, P., McCloskey, E.V., Mellstrom, D., Melton, L.J. 3rd, Meunier, P.J., Pols, H.A., Reeve, J., Silman, A., Tenenhouse, A. Body mass index as a predictor of fracture risk: a meta-analysis. Osteoporos. Int. $2005 ; 16(11): 1330-1338$. doi: 10.1007/s00198-005-1863-y. 
8. Reid, I.R. Relationships among body mass, its components, and bone. Bone. 2002; 31(5): 547 - 555. PMID: 12477567.

9. Thomas, T. Gori, F. Khosla, S. Jensen, M. D. Burguera, B., Riggs, B. L. Leptin acts on human marrow stromal cells to enhance differentiation to osteoblasts and to inhibit differentiation to adipocytes. Endocrinology. 1999; 140(4): $1630-1638 . \quad \underline{\text { doi: }}$ 10.1210/endo.140.4.6637.

10. Alam, R., Kim, S., Lee, J., Chon, S., Choi, S., Choi, H., Kim, N. Effects of safflower seed oil in osteoporosis inducedovariectomized rats. The American Journal of Chinese Medicine 2006; 34(4): 601 - 612. doi: 10.1142/S0192415X06004132.

11. Konturek, P., Konturek, S., Brzozowski, T., Jaworwk, J., Hahn, E. Role of leptin in the stomach and the pancreas. J. Physiol. Paris. 2001; 95(1-6): 345 - 54. PMID: 11595459.

12. Lane, N.E, Yao, W., Kinney, J.H., Modin, G., Balooch, M., Wronski, T.J. Both hPTH(1-34) and bFGF increase trabecular bone mass in osteopenic rats but they have different effects on trabecular bone architecture. J. Bone Miner. Res., 2003; 18(12): 2105-2115. 10.1359/jbmr.2003.18.12.2105.

13. Lelovas, P.P., Xanthos, T.T., Thoma, S.E., Lyritis, G.P., Dontas, I.A. The laboratory rat as an animal model for osteoporosis research. Comp. Med. 2008; 58(5): 424 430. PMID: 19004367.

14. Chen, X, Chen J., Zhang, H.Y., Wang, F.B, Wang, F.F., Ji, X.H, He, Z.K.
Colorimetric Detection of Alkaline Phosphatase on Microfluidic Paper-based Analysis Devices. Chinese J. Analytical Chem. 2016; 44(4): 591-596. https://www.sciencedirect.com/science/articl e/abs/pii/S1872204016609234

15. Risteli, L., Risteli, J. Biochemical markers of bone metabolism. Ann. Med. 1993; 25: 385 - 93. PMID: 8217105.

16. Robins, S.P., Woitge, H., Hesley, R., Ju, J. Seyedin, S., Seibel, M.J. Direct, enzymelinked immunoassay for urinary deoxypyridinoline as a specific marker for measuring bone resorption. J. Bone Miner. Res. 1994; 9(10): 1643 - 9. 10.1002/jbmr.5650091019.

17. Xie, F., Wu, C.F., Lai, W.P., Yang, X.J., Cheung, P.Y., Yao, X.S., Leung, P.C., Wong, M.S. The osteoprotective effect of Herba epimedii (HEP) extract in vivo and in vitro. Evid. Based Complement Alternat. Med. 2005; 2(3): 353 - 61. 10.1093/ecam/neh101.

18. Marino, J.H., Cook, P., Miller, K.S. Accurate and statistically verified quantification of relative mRNA abundances using SYBR Green I and real-time RT-PCR. J. Immunol. Methods 2003; 283(1-2): 291 306. PMID: 14659920.

19. Vandesompele, J., De Preter, K, Pattyn, F., Poppe, B., Van Roy, N., De Paepe, A. Speleman, F. Accurate normalization of real-time quantitative RT-PCR data by geometric averaging of multiple internal control genes. Genome Biol. 2002; 3(7): RESEARCH0034. PMID: 12184808. 
20. Fahmy, S.R., Soliman, A.M., Sayed, A.A, Marzouk, M. Possible antiosteoporotic mechanism of Cicer arietinum extract in ovariectomized rats. Int. J. Clin. Exp. Pathol. 2015; 8(4): 3477 -3490. PMID: 26097532.

21. Raisz, L. Pathogenesis of osteoporosis: concepts, conflicts, and prospects. J Clin Invest. 2005; 115(12): 3318 - 25. doi: $\underline{10.1172 / J C I 27071 .}$

22. Jee, W.S., Yao, W. Overview: animal models of osteopenia and osteoporosis. J. Musculoskelet Neuronal Interact. 2001; 1(3): 193 - 207. PMID: 15758493.

23. Su, S.J., Yeh, Y.T., Shyu, H.W. The preventive effect of biochanin a on bone loss in ovariectomized rats: involvement in regulation of growth and activity of osteoblasts and osteoclasts. Evid. Based Complement Alternat. Med. 2013; 2013: 594857. doi: 10.1155/2013/594857.

24. Zhao, X., Wu, Z., Zhang, Y., Yan, Y., He, Q., Cao, P., Lei, W. Anti-osteoporosis activity of Cibotium barometz extract on ovariectomy-induced bone loss in rats. J. Ethnopharmacol. 2011; 137(3):1083 - 1088. doi: 10.1016/j.jep.2011.07.017.

25. Notomi, T., Okimoto, N., Okazaki, Y., Nakamura, T., Suzuki, M. Tower climbing exercise started 3 months after ovariectomy recovers bone strength of the femur and lumbar vertebrae in aged osteopenic rats. J. Bone Miner. Res. 2003; 18(1): 140 - 149. doi: 10.1359/jbmr.2003.18.1.140.

26. Riggs, B.L., Khosla, S., Melton, L. Sex steroids and the construction and conservation of the adult skeleton. Endocr.
Rev. 2002; 3(3): 279 - 302. 10.1210/edrv.23.3.0465.

27. Bhardwaj, P., Rai, D.V., Garg, M.L. Zinc as a nutritional approach to bone loss prevention in an ovariectomized rat model. Menaupose. 2013; 20(11): 1184 - 93. doi: 10.1097/GME.0b013e31828a7f4e.

28. Cho, J.H., Cho, D.C., Yu, S.H., Jeon, Y.H., Sung, J.K., Kim, K.T. Effect of dietary calcium on spinal bone fusion in an ovariectomized rat model. J. Korean Neurosurg. Soc. 2012; 52(4): 281 - 287. doi: 10.3340/jkns.2012.52.4.281.

29. Abdel-Sater, K.A., Mansour, H. Bone biomarkers of ovariectomised rats after leptin therapy. Bratisl. Lek. Listy. 2013; 114(6): 303 - 7. PMID: 23731039.

30. Wastney, M.E., Martin, B.R., Peacock, M., Smith, D., Jiang, X.Y., Jackman, L.A. Changes in calcium kinetics in adolescent girls induced by high calcium intake. J. Clin. Endocrinol. Metab. 2000; 85(12): 4470 - 5. doi: $10.1210 /$ jcem.85.12.7004.

31. Hassan, H.A., El Wakf, A.M., El Gharib, N.E. Role of phytoestrogenic oils in alleviating osteoporosis associated with ovariectomy in rats. Cytotechnology. 2012; 65(4): 609 - 619. doi: 10.1007/s10616-0129514-6.

32. O'Loughlin, P.D., Morris, H.A. Oestrogen deficiency impairs intestinal calcium absorption in the rat. J Physiol. 1998; 511(Pt 1): 313 - 322. doi: 10.1111/j.14697793.1998.313bi.x.

33. Sheweita, S.A., Khoshhal, K.I. Calcium metabolism and oxidative stress in bone fractures, role of antioxidants. Curr. Drug 
Metab. 2007; 8(5): 519 - 525. PMID: 17584023.

34. Matsunuma, A., Horiuchi, N. Effect of leptin on regulation of renal 25hydroxyvitamin d3 metabolism and maintenance of calcium homeostasis. Journal of Oral Biosciences. 2007; 49 (2): 97-104.

https://www.sciencedirect.com/science/articl e/abs/pii/S1349007907800028

35. He, X.F., Zhang, L., Zhang, C.H., Zhao, C.R., Li, H., Zhang, L.F., Tian, G.F., Guo, M.F., Dai, Z., Sui, F.G. Berberine alleviates oxidative stress in rats with osteoporosis through receptor activator of NF-kB/receptor activator of NF-kB ligand/osteoprotegerin (RANK/RANKL/OPG) pathway. Bosn. J. Basic Med. Sci. 2017; 17(4):295-301. doi: $\underline{10.17305 / \mathrm{bjbms} .2017 .2596 .}$

36. Li, C.W., Liang, B., Shi, X.L., Wang, H. Opg/Rankl mRNA dynamic expression in the bone tissue of ovariectomized rats with osteoporosis. Genet Mol Res. 2015; 14(3): 9215 - 24. doi: 10.4238/2015.

37. Mai, Q.G., Zhang, Z.M., Xu, S., Lu, M., Zhou, R.P., Zhao, L., Jia, C.H., Wen, Z.H., Jin, D.D., Bai, X.C. Metformin stimulates osteoprotegerin and reduces RANKL expression in osteoblasts and ovariectomized rats. J. Cell Biochem. 2011; 112(10): 2902 - 9. doi: 10.1002/jcb.23206.

38. Foo, J.P., Polyzos, S.A., Anastasilakis, A.D. Chou, S., Mantzoros, C.S. The effect of leptin replacement on parathyroid hormone, rankl-osteoprotegerin axis and wnt inhibitors in young women with hypothalamic amenorrhea. J Clin.
Endocrinol. Metab. 2014; 99(11): E2252 - 8. doi: 10.1210/jc.2014-2491.

39. Xu, J. Wu, T. Zhong, Z. Zhao, C. Y. Tang, Y., Chen, J. Effect and mechanism of leptin on osteoblastic differentiation of hBMSCs. Zhongguo Xiu Fu Chong Jian Wai Ke Za Zhi. 2009; 23(2): 140-144. PMID: 19275091.

40. Wang, L. Yuan, J.S. Zhang, H.X. Ding, H. Tang, X.G., Wei, Y.Z. Effect of leptin on bone metabolism in rat model of traumatic brain injury and femoral fracture. Chin. J. Traumatol. 2011; 14(1): 7 - 13. PMID: 21276361.

41. Ogueh, O, Sooranna S, Nicolaides KH, Johnson MR. The relationship between leptin concentration and bone metabolism in the human fetus. J. Clin. Endocrinol. Metab. 2000; 85(5): $1997 \quad-9 . \quad \underline{\text { doi: }}$ 10.1210/jcem.85.5.6591.

42. Driessler, F., Baldock, P.A. Hypothalamic regulation of bone. J. Mol. Endocrinol. 2010; 45(4): 175 - 81. doi: 10.1677/JME-10-0015.

43. Takeda, S., Elefteriou, F., Levasseur, R., Liu, X., Zhao, L., Parker, K.L., Armstrong, D., Ducy, P., Karsenty, G. Leptin regulates bone formation via the sympathetic nervous system. Cell. 2002; 111(3): 305 - 17. PMID: 12419242.

44. Yadav, V.K., Oury, F., Suda, N., Liu, Z.W., Gao, X.B., Confavreux, C., Klemenhagen, K.C., Tanaka, K.F., Gingrich, J.A., Guo, X.E., Tecott, L.H., Mann, J.J., Hen, R., Horvath, T.L., Karsenty, G. A serotonin-dependent mechanism explains the leptin regulation of bone mass, appetite, and energy expenditure. 
Cell. 2009; 138(5): 976 - 89.

10.1016/j.cell.2009.06.051.

45. Pralong, F.P., Roduit, R., Waeber, G., Castillo, E., Mosimann, F., Thorens, B., Gaillard, R.C. Leptin inhibits directly glucocorticoid secretion by normal human and rat adrenal gland. Endocrinology. 1998;

139(10): $4264 \quad-\quad 8 . \quad \underline{\text { doi: }}$

$\underline{10.1210 / \text { endo.139.10.6254. }}$ 